\title{
Regulation of Flavin Synthesis by Escherichia coli
}

\author{
By A. C. WILSON* and A. B. PARDEE $\dagger$ \\ Biochemistry Department, Virus Laboratory and Virology Department, \\ University of California, Berkeley, California, U.S.A.
}

(Received 24, August 1961)

\section{SUMMARY}

An approach has been made to the problem of how the synthesis of coenzymes is regulated. Two aspects of the problem have been studied, especially as they concern the synthesis of flavins by bacteria:

(1) How are coenzymes prevented from being synthesized as fast as amino acids or nucleic acid bases?

(2) How is coenzyme synthesis adjusted to the often changing physiological needs of bacteria?

Evidence is presented that flavins cannot inhibit the activity of enzymes in the flavin biosynthetic pathway of Escherichia coli, but the amount of these enzymes can be made to vary by a factor of at least two. Repression might, therefore, account for the low rate of flavin synthesis. The possibility that repression rather than feedback inhibition also accounts for the low rate of synthesis of other coenzymes is discussed.

Flavin synthesis is not as precisely adjusted to the physiological needs of bacteria as are syntheses of major metabolites for the following reasons:

(1) Flavins are greatly overproduced by bacteria during exponential growth; the ratio of flavins excreted to flavins retained in the cells is between 0.8 and 8 for all strains and cultural conditions tested.

(2) Flavin synthesis is not tightly geared to growth; thus, flavin synthesis goes on uninterrupted for more than an hour when the growth rate of E. coli or Pseudomonas fluorescens is abruptly reduced from a rapid rate to zero; also growth goes on uninterrupted for over an hour when the flavin supply is abruptly cut off from rapidly growing lactic acid bacteria. Evidently the control mechanism in the flavin pathway is not very sensitive to physiological needs. This conclusion probably applies to other coenzymes as well.

Some incidental findings of interest from other points of view were:

(1) Although internal flavins can get out of $E$. coli, external flavins apparently cannot enter. This could account for the absence of flavinless mutants.

(2) After brief treatment with penicillin, E. coli becomes permeable to external flavins while remaining both impermeable to inulin and capable of synthesizing flavins.

(3) Less than $4 \%$ of the intracellular flavins of $E$. coli are free, in a form that can be extracted with $n$-butanol $(5 \%, \mathrm{v} / \mathrm{v})$, toluene $(0.05 \%, \mathrm{v} / \mathrm{v})$, cetyl trimethylammonium bromide $(0.001 \%, \mathrm{w} / \mathrm{v})$ or distilled water. The remaining flavins are bound, in a form that can be extracted with trichloracetic acid $(5 \%, \mathrm{w} / \mathrm{v})$. The intracellular concentration of free flavins in $E$. coli is estimated to be less than $4 \times 10^{-6} \mathrm{M}$.

* Present address: Graduate Department of Biochemistry, Brandeis University, Waltham, Massachusetts, U.S.A.

† Present address: Biology Department, Princeton University, Princeton, New Jersey, U.S.A. 


\section{IN'TRODUC'TION}

Coenzymes are synthesized very slowly. For the average coenzyme the rate is under ten molecules per bacterium per second or, about a thousand times less than the rate at which the aver ige amino acid or nucleic-acid base is synthesized by bacteria growing rapidly in ninimal media (McIlwain, 1946a). One wonders therefore what mechanisms are used to prevent a coenzyme from being synthesized as fast as an amino acid or nucleic-acid base.

Up till now, metabolic control mechanisms have been studied almost entirely in the pathways by which amino acids and nucleic-acid bases are synthesized, as is evident from recent reviews appearing in the Cold Spring Harbor Symposia on Quantitative Biology, volume 26 (1962), and elsewhere (Pardee, 1959; Wilson \& Pardee, 1962). These studies le ad us to suggest four possible mechanisms for explaining the low rate of coenzyme synthesis:

(1) The quantities of some enzymes in the biosynthetic pathway of a coenzyme are very low, as a result of a strong inhibition of their formation exerted by the coenzyme (repression).

(2) The quantity of these enzyr aes is very low, as a result of a constitutively low rate of enzyme formation, not attributable to inhibition by the coenzyme.

(3) The activity of these enzyr es is very low, as a result of strong inhibition of their activity by the coenzyme ( $\mathrm{f}$ sedback inhibition).

(4) The activity of these enzyrnes is very low, as a result of an inherently low catalytic activity, not attributable to feedback inhibition.

As well as explaining the low rate of coenzyme synthesis, mechanisms 1 and $\mathbf{3}$ might enable the rate of coenzyme synthesis to be adjusted to changing physiological needs.

In this article we present evidence concerning which of the four mechanisms may operate in the biosynthetic pathways of coenzymes, in particular the pathway by which flavins are synthesized in Escherichia coli and some other bacteria. This pathway was chosen because of the comparative ease with which flavins can be assayed in the tiny amounts for nd in small samples of exponentially growing cultures.

\section{METHODS}

Organisms. Five different species of bacteria were used, three of which can synthesize flavins, namely Bacillus subtilis strain 23, Pseudomonas fuorescens strain A312, and the Escherichia coli strains B (wild type), C (wild type), 43-5 (leucineless), $1 \mathrm{~K} 4$ (threonineless), B96 (purineless), $\mathrm{P}^{-}$(purineless), M 45 B 4 (purineless), ATCC No. 12651 (vitamin- $\mathrm{B}_{6}$-less), M 4834 ( $p$-aminobenzoateless), and $\mathrm{K} 12 / 3000$ (thiamineless). The other two species, which cannot synthesize flavins, were Lactobacillus casei (ATCC No. 7469) and a nameless Streptococcus sp. (ATCC No. 10100).

Media. Stock cultures of Escherichia coli, Bacillus subtilis and Pseudomonas fluorescens were maintained on agar slants containing 'complete' medium (Lederberg, 1950). The two lactic acid bacteria were maintained as stab cultures in the same medium. All stock cultures were stored at $4^{\circ}$ between transfers, which were at bimonthly intervals. Experiments were generally carried out with bacteria growing exponentially in liquid culture aerated by swirling in conical flasks either 
at $30^{\circ}$ (for $\boldsymbol{P}$. fluorescens) or $37^{\circ}$ (for the other species). The minimal medium for growth of $\boldsymbol{E}$. coli, $\boldsymbol{B}$. subtilis and $\boldsymbol{P}$. fluorescens was Davis's minimal salt solution (Lederberg, 1950) together with either glycerol, glucose or glycollic acid as the sole carbon source, usually at a concentration of $2 \mathrm{mg} . / \mathrm{ml}$. The glycollic acid was sterilized by filtration. For growth of $E$. coli mutants, $15-20 \mu \mathrm{g} . / \mathrm{ml}$. of the required amino acid or purine or $1 \mu \mathrm{g} . / \mathrm{ml}$. of the required vitamin was added to minimal medium. In some experiments $\boldsymbol{E}$. coli was grown on supplemented media: $(a)$ the 'rich glycerol ' medium, which consisted of glycerol minimal medium together with Difco casamino acids ( $1 \mathrm{mg} . / \mathrm{ml}$.), tryptophan, uracil and adenine $(50 \mu \mathrm{g} . / \mathrm{ml}$. of each); or $(b)$ the 'rich glucose' medium, which contained peptone, tryptone, yeast extract and beef extract (Difco products, $1 \mathrm{mg} . / \mathrm{ml}$. of each) together with glucose (2.5 mg. $/ \mathrm{ml}$.) $\mathrm{K}_{2} \mathrm{HPO}_{4} \cdot 3 \mathrm{H}_{2} \mathrm{O}\left(3 \mathrm{mg} . / \mathrm{ml}\right.$.) and $\mathrm{KH}_{2} \mathrm{PO}_{4}(1 \mathrm{mg} . / \mathrm{ml}$.). The lactic acid bacteria were grown in riboflavin assay medium (Snell, 1950) plus riboflavin $(0 \cdot 1 \mu \mathrm{g} . / \mathrm{ml}$.).

Assays. Bacterial growth was determined with a Klett-Summerson colorimeter (green filter) or by measurement of total protein precipitable by cold $5 \%(\mathrm{w} / \mathrm{v})$ trichloracetic acid (Lowry, Rosebrough, Farr \& Randall, 1951).

Flavins were extracted from bacteria and their concentration determined by the fluorimetric method recommended by Burch (1957) for mammalian cells, but with the following modifications. First, flavins were routinely extracted by exposing bacteria to trichloracetic acid $(5 \%, \mathrm{w} / \mathrm{v})$ for $15-60 \mathrm{~min}$ at $0^{\circ}$. Secondly, reproducible results of satisfactory accuracy and sensitivity could be obtained with cuvettes and test tubes that had been cleaned by heating in beakers of $50 \%(\mathrm{v} / \mathrm{v})$ concentrated nitric acid at $100^{\circ}$ for $15 \mathrm{~min}$. All other glassware was cleaned with detergent and all reagent solutions were made up in ordinary distilled water.

High concentrations of flavins were determined by optical density at $450 \mathrm{~m} \mu$ (Peel, 1958), nucleotides by optical density at $260 \mathrm{~m} \mu$, inulin by the modified Roe test (Roe, Epstein \& Goldstein, 1949) and amino acids by the quantitative ninhydrin method of Troll \& Cannan (1953).

Isolation of flavins from culture supernatants. Culture supernatants containing flavin adenine dinucleotide (FAD), flavin mononucleotide (FMN) and riboflavin were made approximately $0 \cdot 1 \mathrm{~N}$ with respect to $\mathrm{HCl}$ and left at room temperature in darkness for 2 days to hydrolyse FAD to FMN. The FMN and riboflavin were then purified together by chromatography on Florisil (60/100 mesh, for which see Peel, 1958) and after this FMN was hydrolysed quantitatively to riboflavin with acid phosphatase (Worthington Biochemical Corporation). The phosphatase was removed with trichloracetic acid and the riboflavin was precipitated with dithionite, crystallized from $80 \%$ isopropanol and recrystallized several times from dilute acetic acid (Plaut, 1954).

Ultraviolet irradiation. Shallow layers of bacterial suspensions were irradiated at a distance of $25 \mathrm{~cm}$. below a Sylvania $15 \mathrm{~W}$. Germicidal-A ultraviolet lamp.

Radioactive counting. Solutions containing less than $3 \mathrm{mg} \cdot{ }^{14} \mathrm{C}$-labelled riboflavin were dried on nickel planchets and counted with an end-window gas-flow counter. Each sample was counted long enough to give at least 500 counts above background, which was about 18 counts/min. 


\section{RESULTS}

Flarin content of bacteria

The flavins of the bacterial cel, like those of cells in general, are in the form of flavin adenine dinucleotide (FAD and flavin mononucleotide (FMN), although there may be a trace of riboflavin as well (Peel, 1958). This has been verified in the present work with Escherichia coli (Table 1). FAD makes up about $60 \%$ of the flavins when $E$. coli is growing on glycer $\supset$ or glucose and when Pseudomonas fluorescens is growing on glucose, but the proportion of FAD rises to about $80 \%$ when $P$. fluorescens is growing on glycollate (Table 1). Peel (1958) found a smaller proportion of FAD, probably because he extrac ted the flavins with $10 \%(\mathrm{w} / \mathrm{v})$ trichloracetic acid at room temperature; under those conditions FAD slowly hydrolyses to FMN.

Table 1. The flavins of exponentially growing Escherichia coli and Pseudomonas fluorescens

\begin{tabular}{|c|c|c|c|c|c|}
\hline \multirow[b]{2}{*}{ Organism } & \multirow[b]{2}{*}{ Growth medium } & \multicolumn{4}{|c|}{ Type of flavin $(\%)$} \\
\hline & & FAD & FMN & $\mathbf{R}^{*}$ & $\mathbf{F M N}+\mathbf{R}$ \\
\hline \multicolumn{6}{|c|}{ Intracellular flavins } \\
\hline E. $\operatorname{coli} \mathbf{B}$ & $\begin{array}{l}\text { Glucose m inimal } \\
\text { Glycerol r rinimal }\end{array}$ & $\begin{array}{l}58 \\
64\end{array}$ & 42 & $\underline{0}$ & $\begin{array}{l}42 \\
36 \dagger\end{array}$ \\
\hline P. fluorescens A 312 & $\begin{array}{l}\text { Glucose m inimal } \\
\text { Glycollate minimal }\end{array}$ & $\begin{array}{l}62 \\
81\end{array}$ & - & - & $\begin{array}{l}38 \dagger \\
19 \dagger\end{array}$ \\
\hline \multicolumn{6}{|c|}{ Extracellular flavins } \\
\hline E. coli B & $\begin{array}{l}\text { Glucose nuinimal } \\
\text { Glycerol I ainimal }\end{array}$ & $\begin{array}{l}15 \\
20\end{array}$ & 52 & 33 & $\begin{array}{l}85 \\
80 \dagger\end{array}$ \\
\hline P. fluorescens A 312 & $\begin{array}{l}\text { Glucose minimal } \\
\text { * R metns ribof } \\
+ \text { FMN and } \mathbf{R} \text { w }\end{array}$ & sep & $-\cdots$ & - & $45 \dagger$ \\
\hline
\end{tabular}

The flavin content of Escherichia coli, Pseudomonas fluorescens and Bacillus subtilis, as determined in the present work, is between 0.21 and $0.33 \mu$ mole/g. protein during exponential growth in all media tested and under anaerobic as well as aerobic conditions. These values are similar to Peel's, although he harvested the bacteria in stationary phase and used different strains and culture media from ours. Apparently such variables do nct affect the flavin content much.

Although a large proportion of the flavins in yeast and vertebrate cells is bound to protein (Euler \& Adler, 1934), in a form that can be extracted with trichloracetic acid (Burch, 1957; Peel, 1958), some flavins are free in solution and some are bound so strongly that they are released only after treatment with proteases (Singer, Kearney \& Massey, 1956; Warringa \& Giuditta, 1958). However, after Escherichia coli was extracted with trichloracetic acid no further flavins were released upon treatment with chymotrypsin or' with $6 \mathrm{~N}-\mathrm{HCl}$ for $8 \mathrm{hr}$. at $105^{\circ}$.

A measure of the size of the soluble flavin fraction has been obtained by treating Escherichia coli with cold aqueous solutions of $n$-butanol, toluene or cetyl trimethylammonium bromide (Cetab), agents which break the osmotic barriers of cells apparently without splitting flavins from flavoproteins. Such agents release small 
molecules from the intracellular pools of bacteria very effectively and permit added small molecules, including flavins (see below, Table 4), to enter the bacteria freely (Bolton, Britten, Cowie \& Roberts, 1955; Mitchell \& Moyle, 1956; Newton, 1958). However, only about $5 \%$ of the flavins extractable by trichloracetic acid are extracted by these agents (Table 2). Under the same conditions, these agents extract $50 \%$ of the soluble nucleotide pool (material absorbing at $260 \mathrm{~m} \mu$ ). (That mild agents do not extract as much material absorbing at $260 \mathrm{~m} \mu$ as does perchloric acid, is probably because perchloric acid extracts bound coenzymes as well as pool nucleotides; in support of this, pellets extracted with the mild agents retain the creamish beige colour of living $E$. coli whereas the pellets are white after treatment with perchloric acid or trichloracetic acid.)

Table 2. Extraction of flavins from Escherichia coli

\begin{abstract}
Escherichia coli B was spun down from samples of a culture growing exponentially in glucose minimal medium and the supernatants were discarded. The walls of the tubes were wiped thoroughly and each pellet of bacteria $(8.7 \mathrm{mg}$. wet weight) suspended in $1 \mathrm{ml}$. of extracting agent at $0^{\circ}$. After $60 \mathrm{~min}$. the bacteria were spun down at $0^{\circ}$ and the supernatants saved for measurement of optical density at $260 \mathrm{~m} \mu$ and for fluorimetric assay of total flavins. The values presented in the last two columns are the amounts extracted by the various agents, expressed as percentages of the amount extracted by the best extracting agent in the particular experiment.
\end{abstract}

\begin{tabular}{|c|c|c|c|}
\hline \multirow[b]{2}{*}{ Expt. } & \multirow[b]{2}{*}{ Extracting agent } & \multicolumn{2}{|c|}{ Percentage extracted } \\
\hline & & Flavin & $\begin{array}{l}\text { Material } \\
\text { absorbing } \\
\text { at } 260 \mathrm{~m} \mu\end{array}$ \\
\hline 1 & $\begin{array}{l}\text { Trichloracetic acid, } 5 \%(\mathrm{w} / \mathrm{v}) \\
\text { Toluene, } 0 \cdot 05 \%(\mathrm{v} / \mathrm{v}) \\
n \text {-Butanol, } 5 \%(\mathrm{v} / \mathrm{v})\end{array}$ & $\begin{array}{r}100 \\
9 \\
5\end{array}$ & - \\
\hline 2 & $\begin{array}{l}\text { Trichloracetic acid, } 5 \%(\mathrm{w} / \mathrm{v}) \\
\text { Perchloric acid, } 3 \%(\mathrm{w} / \mathrm{v}) \\
n \text {-Butanol, } 5 \%(\mathrm{v} / \mathrm{v})\end{array}$ & $\begin{array}{c}100 \\
73 \\
4 \cdot 4\end{array}$ & $\begin{array}{r}- \\
100 \\
56\end{array}$ \\
\hline 3 & $\begin{array}{l}\text { Perchloric acid, } 5 \%(\mathrm{w} / \mathrm{v}) \\
\text { Cetab, } 0.001 \%(\mathrm{w} / \mathrm{v}) \\
\text { Distilled water }\end{array}$ & $\begin{array}{r}100 \\
7 \\
5\end{array}$ & $\begin{array}{r}100 \\
46 \\
48\end{array}$ \\
\hline
\end{tabular}

The most accurate figure for the percentage of free flavins in Escherichia coli was given by Experiment 2 (Table 2), namely, $4 \cdot 4 \%$, but even this is an upper limit because the pellets could have contained up to $0.002 \mathrm{~m} \mu$ mole flavin in the interstitial space, i.e. nearly $1 \%$ of the total flavin in the pellet. On top of this flavins might be split from flavoproteins to some, as yet unknown, extent, during an hour in contact with these agents. It is therefore not clear how much less than $4 \%$ of the intracellular flavins of $E$. coli are in solution. Since $E$. coli contains at least three parts of water to one part of protein (Roberts et al. 1955) and about $0.3 \mu$ mole flavin/g. protein, there are no more than $0 \cdot 1 \mu$ mole total flavin $/ \mathrm{ml}$., and the concentration of free flavins in $E$. coli is less than $4 \times 10^{-6} \mathrm{M}$.

\title{
Flavin synthesis by growing bacteria
}

Species like Escherichia coli, which do not need an external source of flavins for growth, can synthesize flavins from simple compounds in the medium. In fact, flavins are synthesized much faster than they are needed for growth (e.g. Fig. 1). 
If samples of the bacteria are spun down or filtered from the medium at intervals during exponential growth, the flavin content is found to stay steady at about $\mathbf{0 . 2 7} \mu \mathrm{mole} / \mathrm{g}$. protein. The rest of the flavin synthesized is easily detected in the medium. In the experiment described in Fig. 1, the extent of flavin overproduction, which is defined here as the ratio of excreted flavin to retained flavin, is 1.5.

\section{Table 3. Overproduction of flavins by bacteria}

The experimental technique was as described in Fig. 1. The extent of flavin overproduction, i.e. the ratio of excreted flavins to retained flavins, was calculated from equation (1). Each value given for Escherichia coli B during aerobic growth in minimal media is a mean based on more than ten experiments but other values are derived from one or two experiments.

Species and strain

E. coli B

E. coli C

E. coli $\mathrm{K} 12 / 3000$

E. coli $\mathbf{P}-$

E. coli $1 \mathrm{~K} 4$

E. coli 43-5

E. coli M45B4

E. coli $\mathrm{B96}$

B. subtilis 23

P. fluorescens A312
Growth medium

Glucose minimal
Glycerol minimal
Rich glycerol
Glucose minimal (anaerobic)
Glucose minimal
Glycerol minimal
Glycollate minimal
Glucose minimal
Glycerol minimal
Glycerol minimal
Glycerol minimal
Glycerol minimal
Glycerol minimal
Glucose rninimal
Glucose rninimal

\begin{tabular}{|c|c|c|}
\hline $\begin{array}{l}\text { Extent of } \\
\text { flavin } \\
\text { over- } \\
\text { production }\end{array}$ & $\begin{array}{c}\text { Doubling } \\
\text { time } \\
\text { (min.) }\end{array}$ & $\begin{array}{c}\text { Potential } \\
\text { doubling } \\
\text { time } \\
\text { supportable } \\
\text { by flavin } \\
\text { synthesis } \\
\text { (min.) }\end{array}$ \\
\hline $1 \cdot 7$ & 50 & 18 \\
\hline $1 \cdot 2$ & 61 & 28 \\
\hline 0.8 & 35 & 19 \\
\hline 3.0 & 77 & 19 \\
\hline $2 \cdot 3$ & 54 & 16 \\
\hline $1 \cdot 3$ & 73 & 32 \\
\hline $8 \cdot 1$ & 240 & 28 \\
\hline $1 \cdot 4$ & 77 & 31 \\
\hline $2 \cdot 0$ & 67 & 22 \\
\hline $1 \cdot 6$ & 96 & 35 \\
\hline $1 \cdot 4$ & 52 & 22 \\
\hline $1 \cdot 2$ & 76 & 31 \\
\hline $1 \cdot 6$ & 90 & 32 \\
\hline $1 \cdot 4$ & 77 & 32 \\
\hline 1.5 & 54 & 22 \\
\hline
\end{tabular}

Similar results have been obtained with all other bacterial strains tested that are capable of synthesizing flavins. They include seven other strains of Escherichia coli and one strain each of Pseudomonas fluorescens and Bacillus subtilis (Table 3). During exponential growth all strains excreted $0 \cdot 8$ to 8 times as much flavin as they kept inside themselves. Extensive overproduction of flavins is therefore a widespread phenomenon because these three species belong to different bacterial families (Enterobacteriaceae, Pseudomonadaceae and Bacillaceae). Further evidence of the generality of the phenomenon is that it occurs during aerobic growth in all media tested, including minimal media with a variety of carbon sources (glucose, glycerol and glycollate), the rich glycerol medium, and during anaerobic growth in glucose minimal medium (Table 3 ).

It should be noted that because the flavin content of bacteria stays steady throughout the exponential phase, direct measurements of excreted and retained flavin are not needed to determine the extent of flavin over-production, $E$; for $E$ can be calculated from the expression

$$
E=\frac{\Delta F-\Delta P}{\Delta P},
$$


where $\Delta \boldsymbol{F}$ is the percentage increase in the amount of flavin in the whole culture during a given interval (starting with washed cells at zero time) and $\Delta \boldsymbol{P}$ is the percentage increase in the amount of bacterial protein during the same interval. The results presented in Table 3 have mostly been obtained in this way.

Table 3 also shows that, from the growth rate (doubling time) and the extent of

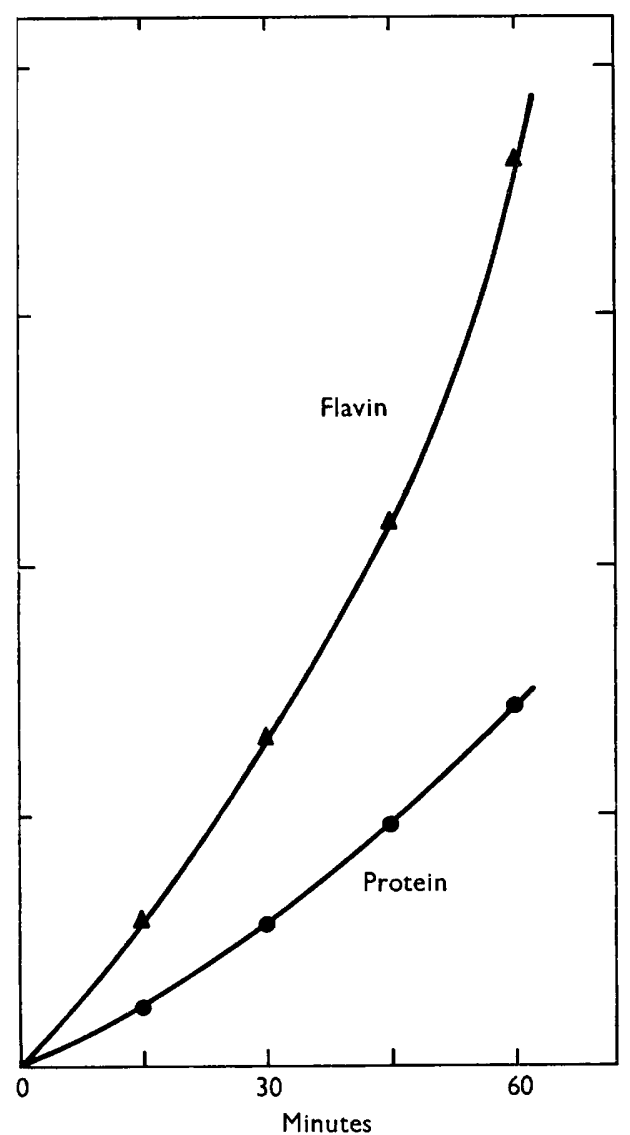

Fig. 1

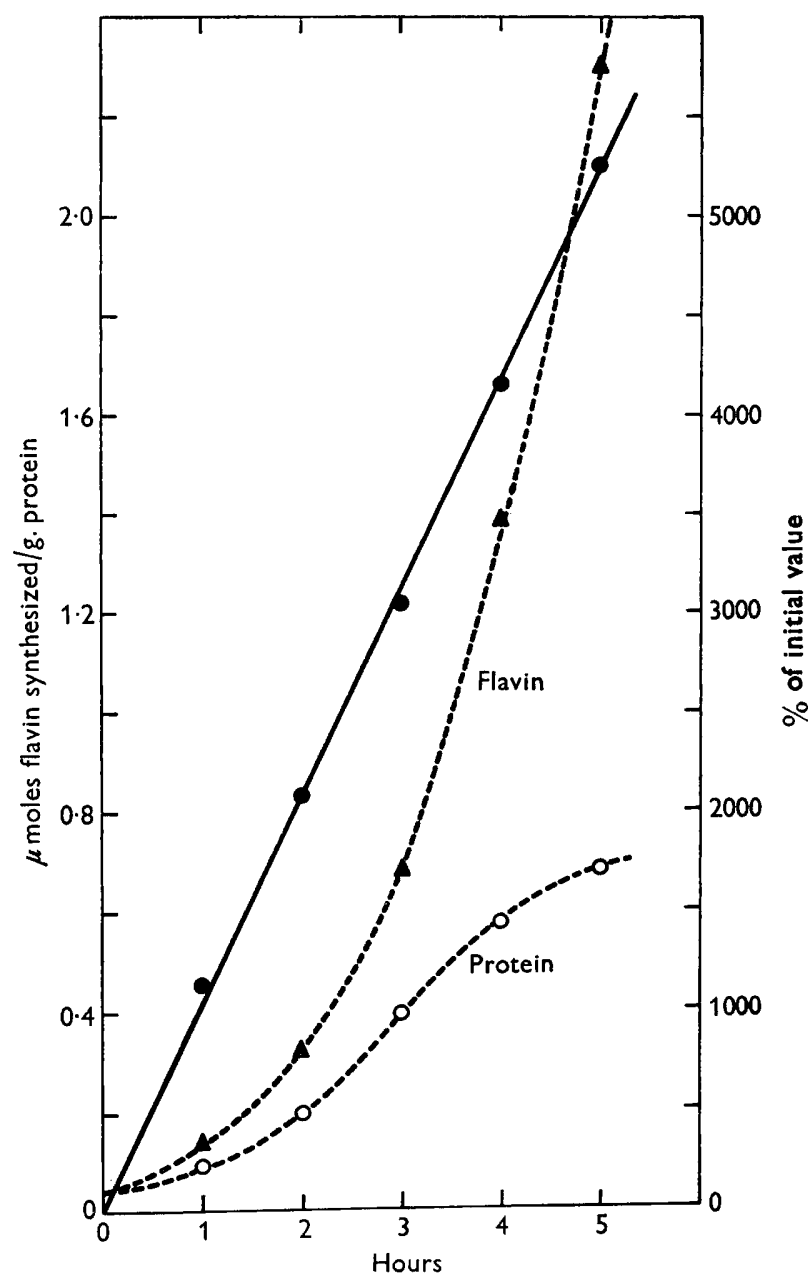

Fig. 2

Fig. 1. Overproduction of flavins by Escherichia coli B. Bacteria growing exponentially in glucose minimal medium were centrifuged down and resuspended in fresh warm medium to let exponential growth resume at once. Samples of the fresh culture were taken into cold $5 \%(\mathrm{w} / \mathrm{v})$ trichloracetic acid at intervals during the succeeding $60 \mathrm{~min}$. for analysis of protein and total flavin.

Fig. 2. The steady rate of flavin synthesis during growth of Escherichia coli B. Bacteria growing exponentially in glycerol minimal medium were spun down and suspended in fresh warm medium at $38 \mu \mathrm{g}$. protein $/ \mathrm{ml}$. to allow exponential growth to resume at once. During the succeeding $5 \mathrm{hr}$., samples were taken for analysis of protein and total flavin. The rate of flavin synthesis (solid line) has been corrected graphically for protein synthesis (cf. McIlwain, 1946b). 
flavin overproduction, one can calculate that bacteria would have to grow at nearly their maximum possible rates if they were to retain all the flavins formed.

The rate of flavin synthesis, expressed in more orthodox units, is between 0.3 and $0.9 \mu \mathrm{mole} / \mathrm{g}$. protein/hr. during exponential growth of all three species. The rate varies with the strain and the medium, and has the same temperature coefficient as the growth rate, at least for Escherichia coli $B$. For a given strain in a given medium at constant temperature, the rate of flavin synthesis is constant throughout exponential phase and beyond, up to the onset of maximum stationary phase, i.e. $d F /$ $\boldsymbol{P} d t=$ constant, $\boldsymbol{F}$ being flavin, $\boldsymbol{P}$ being protein and $t$ being time. This constancy of rate is not immediately evident in Fig. 1 because of the way in which the data are plotted, but it is evident in Fig. 2, for example, where a correction for protein synthesis has been made. Within $2 \mathrm{hr}$. after the onset of stationary phase, however, flavin synthesis becomes severely reduced.

\section{Uncoupling of flavin synthesis and growth}

Flavin synthesis without growth. The growth rate of a culture in exponential phase can be abruptly reduced to approximately zero by inhibiting the synthesis of macromolecules specifically, through the use of suitable doses of ultraviolet light (Hanawalt \& Setlow, 1960; Rushizky, Riley, Prestidge \& Pardee, 1960), 5-methyltryptophan (Pardee, Shore \& Prestidge, 1956) or chloramphenicol (Gale \& Folkes, 1953; Wisseman, Smadel, Hahn \& Hopps, 1954), or by withholding the amino acid or nucleic-acid base needed by an auxotrophic mutant for growth. As a virtually immediate result of inhibiting the synthesis of macromolecules, it would be expected that every amino acid and nucleotide would instantly accumulate within the cell and reduce its own synthesis severely by feedback inhibition of the activity of its biosynthetic enzymes. The same might be expected of flavin synthesis because flavins too are, in a sense, constituents of macromolecules (flavoproteins). Indeed it is well known that the synthesis of amino acids and nucleotides does become severely inhibited immediately under such circumstances and this was verified in the present work.

However, flavin synthesis was not inhibited at all when growth of Escherichia coli was abruptly inhibited with vitraviolet light (Fig. $3 a$ ) or 5-methyl-tryptophan (Fig. $3 b$ ) or by withholding leucine from a leucineless mutant (Fig. $3 c$ ) or purines from a purineless mutant (Fig. $3 d$ ). Under these conditions all the flavin synthesized was excreted. Similar results were obtained when threonine was withheld from a threonineless mutant (Escherichia coli $1 \mathrm{~K} 4$ ), or when purines were withheld from two other purineless mutants ( $E$. coli $\mathrm{B} 96$ and $\mathbf{P}^{-}$), or when $P$ seudomonas fluorescens was irradiated heavily with ultraviolet light. But when chloramphenicol was added to exponentially growing $E$. coli B cultures, flavin synthesis was not sustained for long at the rate characteristic of growing bacteria (Fig. $3 b$ ). Within 15 min. after adding the inhibitor the rate of flavin synthesis began to fall, possibly because of some secondary detrimental effect of chloramphenicol on intermediary metabolism as a whole (cf. Pardee \& Prestidge, 1959). What is significant for the problem under consideration is that several independent methods of abruptly reducing the growth rate from a rapid exponential rate to approximately zero do not lead to any adjustment in the rate of flavin synthesis.

Residual growth without vitamins. As is well known, mutants requiring amino 
acids stop growing abruptly and completely as soon as the required amino acid is withdrawn from the medium. In the case of purineless and pyrimidineless mutants the situation is only slightly different, in that a slow increase in turbidity, due to protein synthesis, does go on for an hour or so after withdrawing the required base from the medium (Pardee, 1955).

However, when a required vitamin was suddenly withdrawn from the medium of an exponentially growing culture, growth was at first unaffected in any of four cases

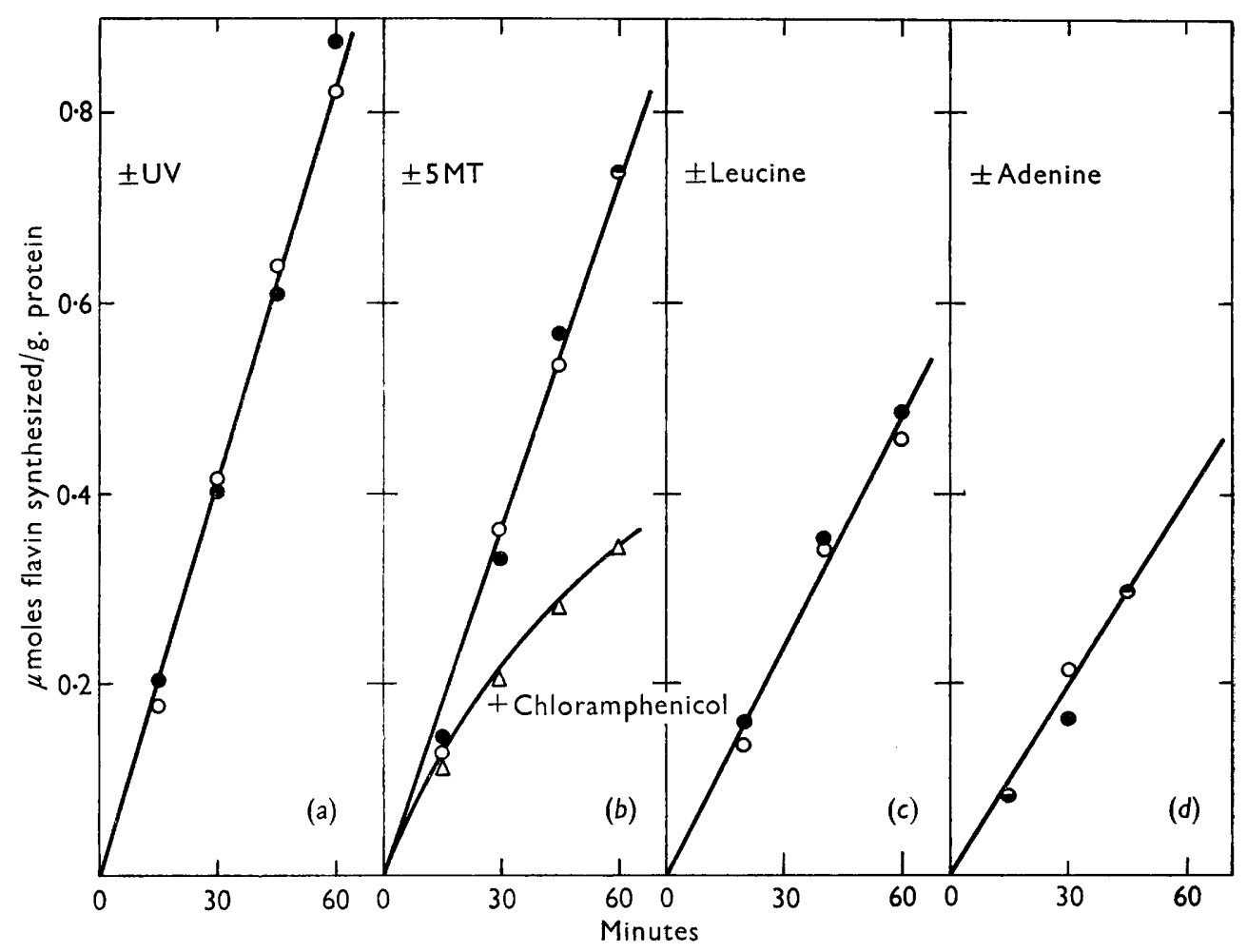

Fig. 3. Synthesis of flavins by Escherichia coli before and after abrupt inhibition of rapid growth. $E$. coli $\mathrm{B}$ was grown in glucose minimal medium and the mutant strains 43-5 and M 45 B4, were grown in glycerol minimal medium supplemented with leucine or adenine. When growth became exponential the bacteria were centrifuged down and resuspended in fresh medium. Growth was allowed to resume immediately in one portion of each suspension but inhibited in the other portion either $(a)$ by a 60 -sec. dose of ultraviolet light (strain B), (b) by $100 \mu \mathrm{g}$. 5-methyl-10L-tryptophan (5 MT) per mI. (strain B) or $50 \mu \mathrm{g}$ chloramphenicol per ml. (strain B) or $(c)$ by omitting leucine (strain 43-5) or (d) adenine (strain M 45 B 4). Samples were then taken into cold $5 \%(w / v)$ trichloracetic acid at intervals during the first $60 \mathrm{~min}$. for analysis of protein and total flavin. In each case, flavin synthesis by the growing culture (solid points) has been corrected for growth mathematically as described by Brooke, Ushiba \& Magasanik (1954) but flavin synthesis by the non-growing culture (empty points) has not been corrected for the trace of protein synthesis that occurred under these conditions.

presented in Fig. 4 or when riboflavin was taken away from the growth medium of Lactobacillus casei. For an hour or more, growth went on exponentially at the same rate as when the vitamin was present; only later did the growth rate slowly decrease. That growth did finally come to a stop after many hours shows that the 
bacteria were not mutants which slowly synthesized the vitamin. Additional evidence against slow flavin synthesis was that the flavin content of the riboflavinrequiring bacteria (Streptococcus species and $L$. casei) declined at least in proportion to the amount of growth in the absence of external riboflavin.

That mass increases of severa fold can take place in the absence of an external supply of a vitamin has been kn jwn for a long time (e.g. Kitay \& Snell, 1948). The
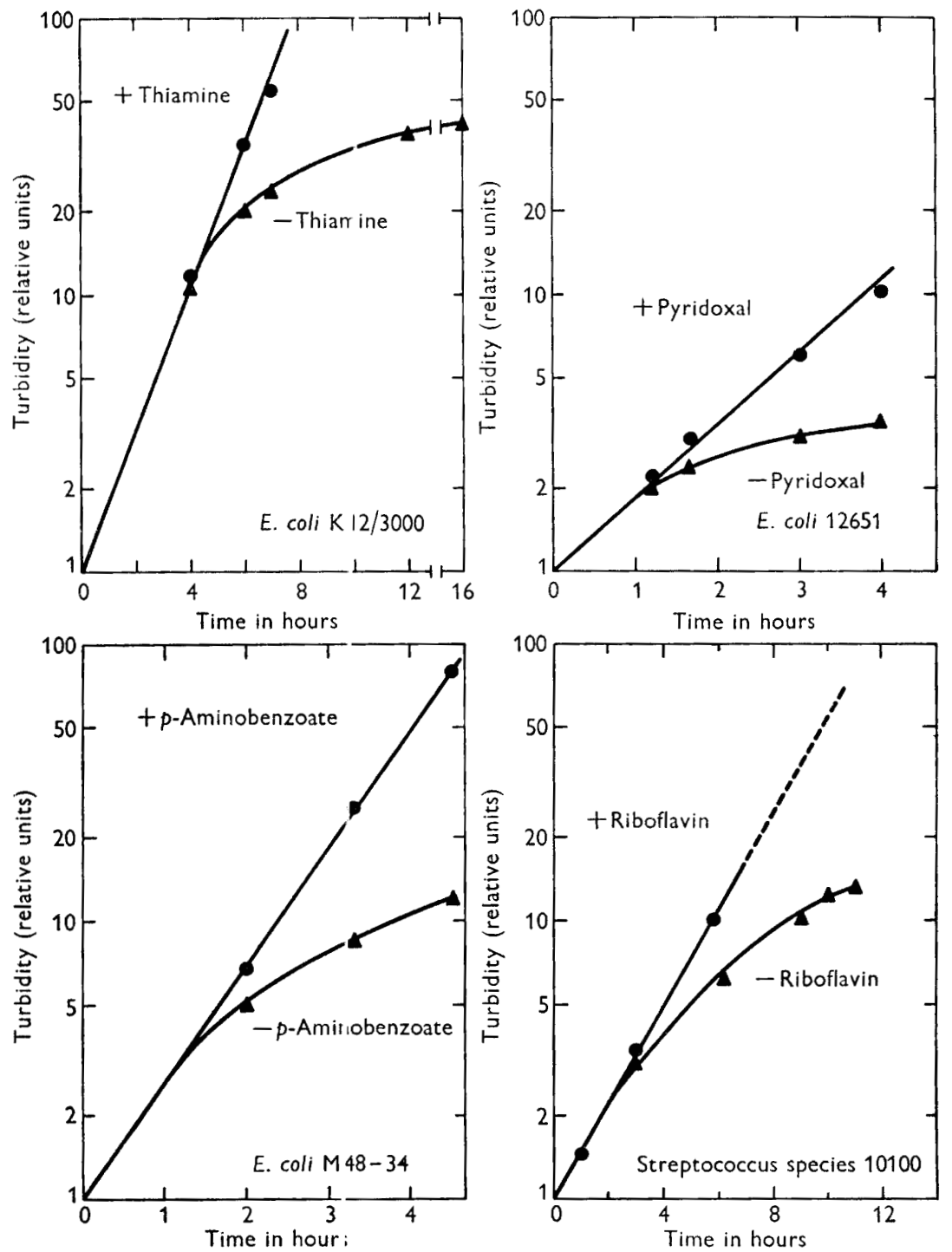

Fig. 4. Residual growth in the absence of an external source of a required vitamin. Four vitamin-requiring strains were grown to exponential phase, centrifuged down from the medium, washed twice by centrifugation in medium lacking the vitamin and finally resuspended in medium with or without the vitamin. The Streptococcus sp. was grown in riboflavin assay medium $( \pm 0 \cdot 1 \mu \mathrm{g}$. ribollavin $/ \mathrm{ml}$. $)$ and the Escherichia coli strains were grown in glucose minimal medium $( \pm 1 \mu \mathrm{g}$. of thiamine, pyridoxal or $p$-aminobenzoate $/ \mathrm{ml}$.). Growth was measured turbidometrically. 
aim here is to draw attention to the early kinetics of the process, which as shown here, demonstrate that bacteria can function very well if the supply of a vitamin, and hence the supply of the corresponding coenzyme(s), is interrupted even for as long as an hour. This should be equally true if the internal synthesis of a coenzyme were interrupted in bacteria that have no dietary need of vitamins. Indeed, when exponentially growing, wild-type Escherichia coli is exposed to folic acid analogues that may inhibit folic acid synthesis, growth goes on at an uninhibited rate for an hour or two before starting to slow down (Webb, 1954). In sum, there is evidence that coenzyme synthesis, including flavin synthesis, can be inhibited for about an hour or more without affecting growth.

\title{
Permeability of Escherichia coli to added flavins
}

As a preliminary to testing the effect of added flavins on flavin synthesis, it was necessary to find out whether bacteria are permeable to added flavins.

Pellet method. Substances to which Escherichia coli is impermeable can occupy about $30 \%$ of the volume of a centrifugal pellet (the interstitial space), whereas

\section{Table 4. Permeability of Escherichia coli to flavins and inulin}

\begin{abstract}
Escherichia coli B was spun down from a culture growing exponentially in glucose minimal medium and suspended in $40 \mathrm{ml}$. of minimal salts. Ten ml. of suspension was put in each of four weighed tubes and the bacteria packed into pellets by centrifugation. The tubes were drained, wiped free of all surface liquids, and weighed again to get the weight of each pellet $(0.25 \mathrm{~g}$.) and hence its volume $(0.25 \mathrm{ml}$.). The bacteria in each pellet were then suspended thoroughly at room temperature in $0.50 \mathrm{ml}$. of minimal salts containing inulin $\left(1 \mathrm{mg} . / \mathrm{ml}\right.$ ) or $\mathrm{FMN}$ and riboflavin (each at $2.6 \times 10^{-3} \mathrm{M}$ ), with or without $0.04 \mathrm{ml}$. $n$-butanol. The bacteria were spun down again after $5 \mathrm{~min}$. and the supernatants analysed for flavins (O.D. ${ }_{450}$ ) or inulin (Roe test).
\end{abstract}

$\begin{array}{lcc} & \begin{array}{c}\text { Percentage of pellet volume } \\ \text { accessible }\end{array} & \overbrace{\begin{array}{c}\text { Untreated } \\ \text { bacteria }\end{array}}^{\begin{array}{c}\text { Butanol-treated } \\ \text { bacteria }\end{array}} \\ \text { Compound } & 28 & 89 \\ \text { Riboflavin + FMN } & 34 & 30\end{array}$

substances to which $E$. coli is permeable can occupy about $75-80 \%$ of the pellet volume (the interstitial space plus the cell water space). Evidence for this is reviewed by Mitchell \& Moyle (1956). Table 4 shows that the percentage of the pellet volume accessible to flavins is about $30 \%$, the same as for inulin, even when FMN and riboflavin are both present at concentrations that are enormous $\left(5 \times 10^{-3} \mathrm{M}\right)$ in comparison with the intracellular concentration of free flavins $\left(4 \times 10^{-6} \mathrm{M}\right)$. Now inulin is a classic example of a substance to which bacteria are impermeable (Mitchell \& Moyle, 1956; Pardee, 1957); so there can be no doubt that flavins cannot enter intact cells under these conditions. They can only enter when the osmotic barriers have been broken with an agent like butanol (Table 4). However, one cannot be certain that these conclusions apply to growing bacteria because the bacteria in the permeability tests were in a different physiological state.

Isotopic method. Isotopic experiments with growing bacteria provide some support for the view that Escherichia coli is impermeable to added flavins. The specific 
activity of the flavins excreted $k$ y $E$. coli growing on radioactive glucose was not altered detectably when high cor centrations of FMN and riboflavin were added to the medium (Table 5). If the added flavins entered the bacteria they would be expected to displace all the newly synthesized flavins into the medium, thereby raising the specific activity of the excreted flavins by about $50 \%$. However, the experimental error in measuring the radioactivity of excreted flavins is large $( \pm 15 \%)$ because they account for less than a ten-thousandth of the cell material synthesized from glucose. Hence. a very slow entry of flavins, perhaps accompanied by a small degree of feedback nhibition, would be consistent with the results. Nonetheless, the simplest explanation of the results is that $E$. coli is impermeable to added flavins.

Table 5. Specific activity of flavins excreted by Escherichia coli during growth with or without added flavins

\begin{abstract}
Escherichia coli B was grown exponentially for $4 \mathrm{hr}$. from turbidity 9 to 112 in two flasks, each containing $165 \mathrm{ml}$. of minimal medium with uniformly labelled $\mathrm{C}^{14}$-glucose as the sole carbon source $\left(1 \mathrm{mg} . / \mathrm{nl} ., 1.5 \times 10^{5}\right.$ counts $/ \mathrm{min} . / \mathrm{mg}$. carbon); one flask also contained ribollavin $\left(8 \times 10^{-5} \mathrm{M}\right)$ and $\mathrm{FMN}\left(8 \times 10^{-5} \mathrm{M}\right)$. The bacteria were removed from the media by centrifugation and hen non-radioactive riboflavin and FMN were added to bring the total amount in eacis supernatant to $20 \mathrm{mg}$. FMN and $15 \mathrm{mg}$. riboflavin. The flavins in each supernatant were converted to riboflavin which was in turn isolated and crystallized repeatedly as des rribed under Methods.
\end{abstract}

\begin{tabular}{|c|c|c|}
\hline \multirow[b]{2}{*}{$\begin{array}{l}\text { Number of } \\
\text { times } \\
\text { crystallized }\end{array}$} & \multicolumn{2}{|c|}{$\begin{array}{c}\text { Specific activity } \\
\text { (counts/min./mg. carbon) }\end{array}$} \\
\hline & $\begin{array}{l}\text { Culture without } \\
\text { added flavins }\end{array}$ & $\begin{array}{l}\text { Culture with } \\
\text { added flavins }\end{array}$ \\
\hline 3 & 33 & 35 \\
\hline 4 & 39 & 35 \\
\hline 5 & 43 & 40 \\
\hline
\end{tabular}

A permeable preparation of Ischerichia coli capable of synthesizing flavins

In view of the evidence that Ischerichia coli is impermeable to external flavins, attempts were made to develop a permeable preparation that retained the ability to synthesize flavins. The best ajpproach seemed to be to find an agent milder than aqueous butanol, one that would weaken the permeability barriers without interfering seriously with metabolism. It was found that penicillin could act in this way. E. coli B was treated for a few ninutes with penicillin while growing exponentially in a rich glucose medium and then spun down from the medium and suspended at high turbidity in a lactate-salts mixture. When this preparation was shaken at $37^{\circ}$ there was no net synthesis of protein but flavins were synthesized steadily for an hour or more (Fig. $5 a, b$; solid circles) at about a third of the rate of flavin synthesis by growing $E$. coli.

Besides fulfilling the requirement of synthesizing flavins, the preparation fulfils the permeability requirements. T'able 6 shows that bacteria grown for a few minutes in the rich medium with penicil in retain their complete impermeability to inulin, yet have become permeable to both FMN and riboflavin. The permeability to riboflavin would appear to be complete, but the data suggest that FMN may still en- 
counter some difficulty in entering. Another test showed that such bacteria are nearly as permeable to $o$-nitrophenyl galactoside as bacteria treated with toluene (cf. Prestidge \& Pardee, 1957). Moreover, many small molecules start to leak from Escherichia coli after a few minutes of growth in penicillin (Prestidge \& Pardee, 1957; Maas, 1959a). In conclusion, $E$. coli grown for a few minutes in a rich medium plus penicillin has enhanced permeability towards many small molecules, including flavins; yet the bacteria cannot have lysed because they retained their impermeability to inulin.

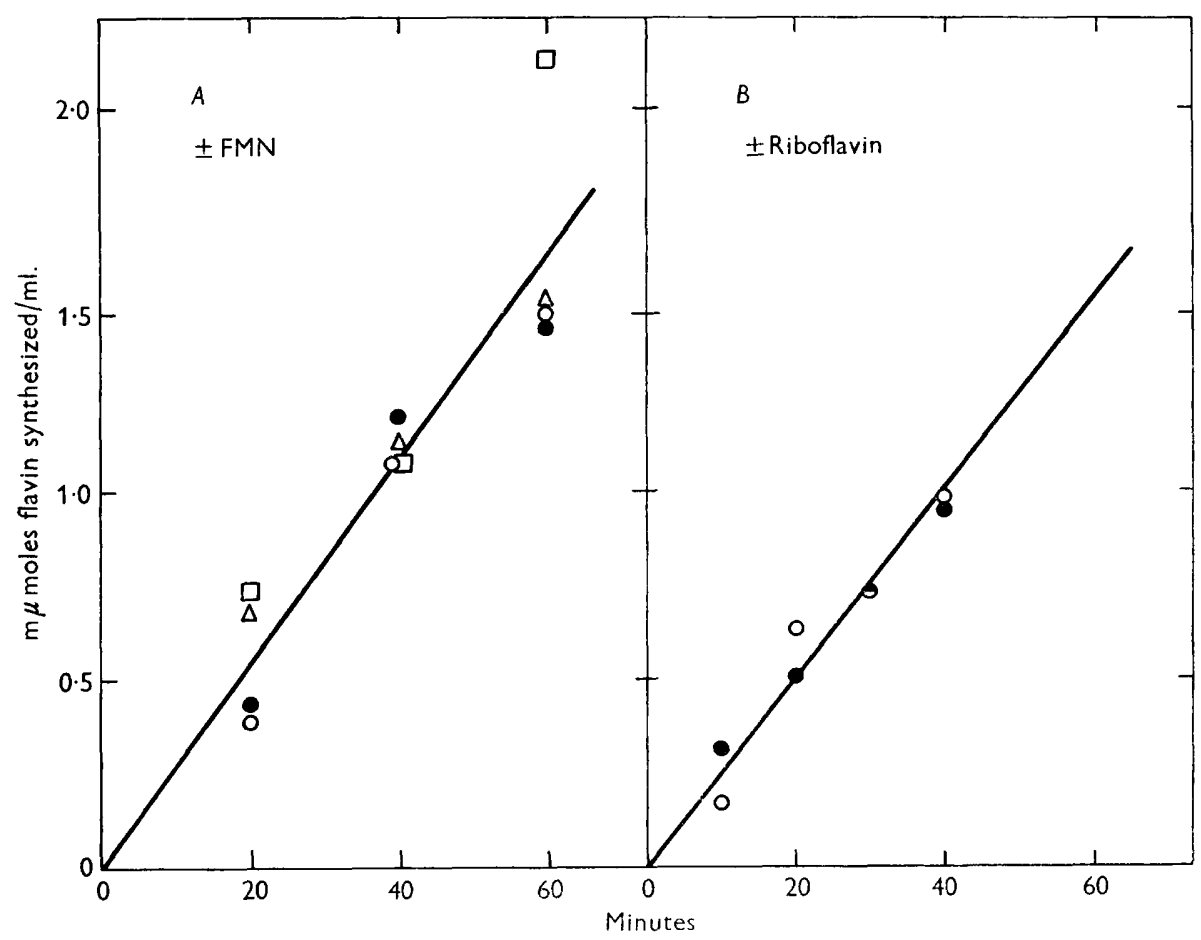

Fig. 5. Effect of added flavins on flavin synthesis by penicillin-treated Escherichia coli B. Bacteria were treated with penicillin for $12 \mathrm{~min}$. as described in Table 6, centrifuged down and resuspended at a concentration of about $25 \mathrm{mg}$. wet weight $/ \mathrm{ml}$. in minimal salts plus potassium lactate $(10 \mathrm{mg} . / \mathrm{ml}$.). Then $2.90 \mathrm{ml}$. of suspension was put in each of several flasks containing $0.09 \mathrm{ml}$. minimal salts plus enough flavin to give a final concentration of $0(0), 2 \cdot 6 \times 10^{-6} \mathrm{M}(\triangle), 5.3 \times 10^{-6} \mathrm{M}(\square)$ or $8 \times 10^{-6} \mathrm{M}(O)$. The flavin was FMN in Expt. $A$ and riboflavin in Expt. $B$. The flasks were shaken at $37^{\circ}$ and samples were taken at intervals during the first $60 \mathrm{~min}$. for analysis of total flavin.

To test whether added flavins can inhibit the activity of the flavin-synthesizing enzymes would, therefore, seem possible with this preparation. Such tests have been carried out with FMN (Fig. 5a) and riboflavin (Fig. 5b). As the figure shows, these flavins at concentrations up to $8 \times 10^{-6} \mathrm{M}$ do not affect the rate of flavin synthesis appreciably. Since the test concentrations are probably at least as high as the normal intracellular concentration of flavins (less than $4 \times 10^{-6} \mathrm{M}$ ), and since the intracellular concentration in penicillin-treated bacteria is probably much lower than normal, the results suggest that in intact bacteria flavin synthesis is not normally being held down by feedback inhibition of enzyme activity. 
Table 6. Permeability of penicillin-treated Escherichia coli to flavins and inulin

Escherichia coli B was grown to exponential phase in a rich glucose medium. Then penicillin was added to a portion of the culture to give a concentration of $100 \mu \mathrm{g} . / \mathrm{ml}$. After 10-12 min. of further growth the bacteria were spun down and suspended in minimal salts. The bacteria in aliquots of the suspensions were then packed into pellets by centrifugation in weighed tubes and the percentage of the pellet volume accessible to inulin, FMN and riboflavin was neasured as described in Table 4.

$\begin{array}{clcc}\text { Expt. } & \text { Compound } & \begin{array}{c}\text { Untreated } \\ \text { bacteria }\end{array} & \begin{array}{c}\text { Penicillin- } \\ \text { treated } \\ \text { bacteria }\end{array} \\ 1 & \text { Riboflavin } & 35 & 73 \\ 2 & \text { FMN } & \mathbf{3 7} & 61 \\ & \text { Riboflavin } & - & \mathbf{8 1} \\ & \text { FMN } & - & 57 \\ \text { Inulin } & - & 27\end{array}$

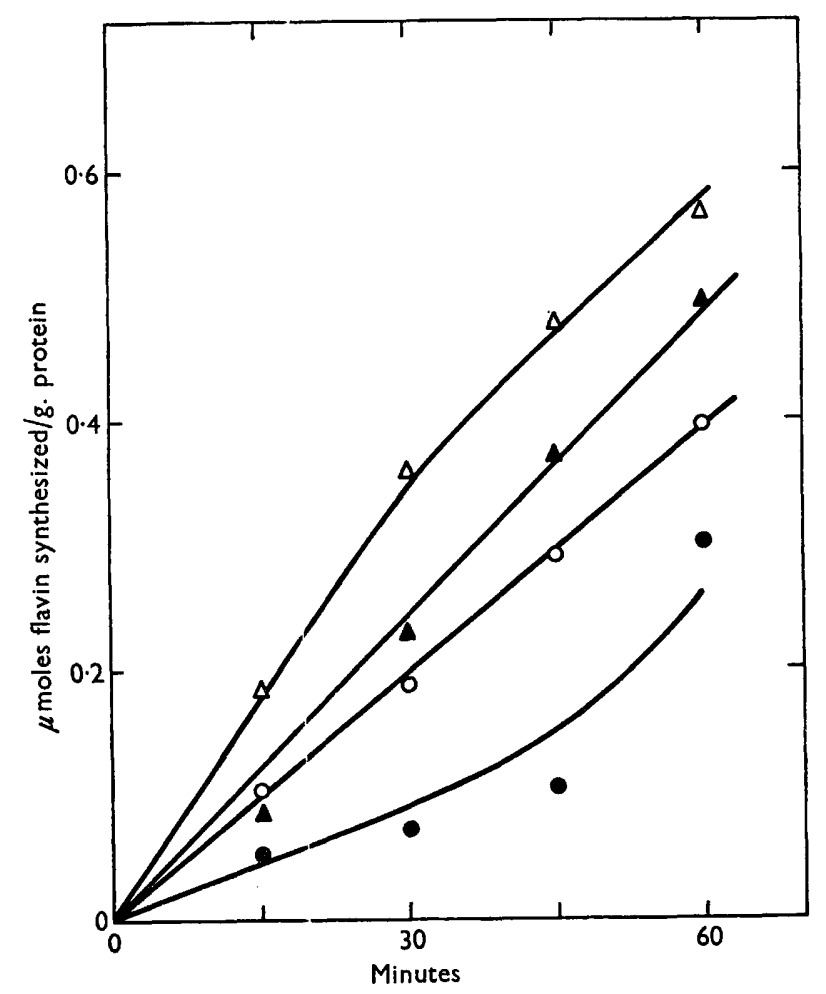

Fig. 6. Flavin synthesis after growth in rich and poor media. Escherichia coli B was grown to exponential phase in the 'rich glycerol' medium (triangles) and in glycerol minimal medium (circles), centrifuged down and resuspended in fresh media of both kinds. During the succeeding $60 \mathrm{~min}$. of growth samples were taken from each culture for analysis of protein and total flavin. Solid symbols refer to flavin synthesis in the rich medium and empty symbols to flavin synthesis in the minimal medium. 


\section{Effect of rich and poor media on flavin synthesis by Escherichia coli}

Several attempts have been made to find out whether the flavin-synthesizing enzymes can vary in amount according to the cultural conditions. Success has been achieved so far in only one type of experiment (Fig. 6). Escherichia coli B was grown to exponential phase in minimal medium and in a rich medium lacking flavins and then the bacteria from each culture were spun down and resuspended in media of both types. During the succeeding $\mathbf{3 0}$ min. in minimal medium the bacteria from the rich medium synthesized flavin twice as fast as bacteria from the minimal medium. During the same time in rich medium somewhat lower rates of flavin synthesis were observed, but again bacteria from the rich medium synthesized flavins twice as fast as bacteria from minimal medium. Afer $\mathbf{3 0} \mathrm{min}$. the rates of flavin synthesis began to adapt to the new media. When the experiment was repeated by suspending bacteria, grown in the minimal or the rich medium, in minimal medium containing chloramphenicol to prevent enzyme synthesis, the twofold difference in rate of flavin synthesis was maintained for at least $60 \mathrm{~min}$. It is likely that this difference in rates of flavin synthesis reflects a difference in the amount of flavin-synthesizing enzymes in bacteria grown on rich and minimal media.

The presence of high concentrations of both riboflavin and FMN $\left(8 \times 10^{-5} \mathrm{M}\right.$ each $)$ during many generations of growth in the rich and minimal media had no effect on the rate at which Escherichia coli B synthesized flavins in minimal medium containing chloramphenicol. This is consistent with the evidence that $E$. coli is impermeable to added flavins.

\section{DISCUSSION}

Mechanisms underlying the low rate of flavin synthesis

Feedback inhibition. Flavins evidently do not inhibit the activity of flavinsynthesizing enzymes. One line of evidence is provided by the experiments with Escherichia coli made permeable to flavins by penicillin. A second line of evidence comes from the experiments with specific inhibitors of the synthesis of macromolecules. The internal concentration of free flavins must rise markedly in the presence of such inhibitors because flavins are not being drained off into flavoproteins, yet the observation was that flavin synthesis was not inhibited at all. It is therefore unlikely that feedback inhibition is responsible for the low rate of flavin synthesis in comparison with amino acid synthesis.

Ideally, other experiments could be done to test whether flavins inhibit the activity of flavin-synthesizing enzymes, even though none of the early enzymic steps of flavin synthesis are known, for example, isotopic competition experiments (Roberts et al. 1955) and experiments on the excretion of biosynthetic intermediates by mutants with a genetic block in the pathway. Unfortunately, because Escherichia coli, like Ashbya gossypii (Maley \& Plaut, 1959), is impermeable to added flavins it has been impossible to carry out isotopic competition experiments or to isolate flavinless mutants, despite deliberate attempts by ourselves and others (e.g. Davis, 1950) to do so.

Further evidence against feedback inhibition can be drawn, nevertheless, from work that has been done on the terminal steps in flavin synthesis. Studies with the purified enzyme that catalyses the conversion of ribityl lumazine to riboflavin 
suggest that its specific activity (uninhibited) in intact cells is about $1 \mu$ mole riboflavin formed/g. protein/hr. in Escherichia coli and several other bacteria and fungi (Plaut, 1960 and unpublished). And the last two enzymes in the pathway, flavokinase and FAD synthetase, have specific activities of probably less than $1 \mu$ mole substrate converted/g. p.otein/hr. in intact brewer's yeast (Schrecker \& Kornberg, 1950; Kearney \& Englıırd, 1951) and Lactobacillus arabinosus (Snoswell, 1957). Consequently, the enzymes are not in appreciable excess over the amount needed to support the observed rate of flavin synthesis by rapidly growing bacteria (0.3-0.9 $\mu \mathrm{mole} / \mathrm{g}$. protein/hr. for Lscherichia coli, Bacillus subtilis and Pseudomonas fluorescens). Yet a huge excess of (nzyme would be expected if feedback inhibition alone accounted for the low rate $\mathrm{c} f$ flavin synthesis.

Feedback inhibition may also he unimportant in the biosynthetic pathways of other coenzymes. Thus, one enzym: in the pathway of pyridine nucleotide synthesis, nicotinic-acid-mononucleotide pyr sphosphorylase, has a specific activity of about $1 \mu$ mole nicotinic acid mononucleotide formed/g. protein/hr. in Escherichia coli, an organism that synthesizes pyridize nucleotides at the rate of about $1 \mu$ mole/g. protein/hr. (Imsande, 1961). And at least two enzymes in the pathway of folic acid synthesis have similarly low activities in Lactobacillus arabinosus (Shiota, 1959) and yeast (Weiss \& Srinivasan, 1959).

Repression. The formation of enzymes in the flavin biosynthetic pathway is evidently influenced by nutritional sonditions. Resting-cell suspensions of Escherichia coli synthesize flavins more slowly if the bacteria have been grown previously in minimal medium instead of a rich medium (cf. Fig. 6). Now in minimal medium growth is slower and a smaller fraction of the flavin synthesized during growth is incorporated into flavo proteins than in a rich medium. Because of this the intracellular concentration of free flavins during growth might be higher in minimal medium than in a rich medium. Ccnsequently, repression by flavins might account for the apparently low level of flavin-synthesizing enzymes in bacteria grown in minimal medium.

Also, the large increase in the final yield of riboflavin synthesized by Ashbya gossypii brought about by surface active agents might be due to de-repression of the flavin-synthesizing enzymes (Sinith, Smith \& Papadoupoulou, 1961).

Much better evidence is available for some other coenzymes, especially pyridine nucleotides which can inhibit their own synthesis in Escherichia coli by inhibiting the synthesis of nicotinic-acid-mınonucleotide pyrophosphorylase (Imsande \& Pardee, 1962). The level of pyrdoxal phosphokinase in vitamin- $\mathrm{B}_{6}$-requiring lactic-acid bacteria can vary accorling to the concentration of vitamin $B_{6}$ in the growth medium (MacCormick, Gregory \& Snell, 1961). Enzymes of folic acid synthesis may also be repressible because when wild-type bacteria grow in the presence of sulphonamides, or when $p$-aminobenzoateless mutants grow on limiting amounts of $p$-aminobenzoate, they become deficient in folic acid and at the same time markedly improve their ability to synthesize folic acid from $p$-aminobenzoate in resting-cell suspensions (Nimmo Smith, Lascelles \& Woods, 1948; Lascelles \& Woods, 1952). If these latter findings were to be substantiated they would become of historical interest because they antedated by several years the first reports of repression in any biosynthetic pathways.

Other mechanisms. There is no evidence concerning whether mechanisms other 
than repression, for example, mechanisms 2 and 4 , have a role in determining the low rate of coenzyme synthesis. Mechanism 2 (constitutively low rate of enzyme formation) would seem more likely than mechanism 4 (enzymes with low turnover number) to have such a role because it would be uneconomical for bacteria to synthesize huge amounts of enzymes with a very low turnover number.

\section{The adjustment of flavin synthesis to physiological needs}

Granting that the rate of coenzyme synthesis is about 1000 times lower than the rate at which the average amino acid or nucleic-acid base is synthesized, we can ask how precisely this low rate is adjusted to the physiological needs of bacteria. The precision of adjustment is rather poor by comparison with that in the synthesis of amino acids and nucleic-acid bases, according to several criteria.

Overproduction. One such criterion is excretion or overproduction. The excretion of a biosynthetic end product signifies that the control mechanisms in the pathway are too weak to prevent the compound from being overproduced (Moyed, 1960; Ennis \& Gorini, 1961). Moreover, the extent of overproduction, i.e. the ratio of end product excreted to end product retained, should be a measure of the weakness of these control mechanisms. According to this criterion, the control mechanisms in large-scale biosynthetic pathways are strong, because, as is well known, their end products are not found in easily detectable amounts outside the cells of bacteria growing exponentially in minimal media. Thus, sensitive methods have revealed that the extent of overproduction is about 0.01 or less for many amino acids synthesized by Escherichia coli, Pseudomonas aeruginosa and a Vibrio sp. (Roberts et al. 1955; Dagley \& Johnson, 1956), less than 0.01 for the porphyrins synthesized by the photosynthetic bacterium, Rhodopseudomonas spheroides (Lascelles, 1961) and about 0.05 or less for the nucleic-acid bases synthesized by $\boldsymbol{E}$. coli (Wilson \& Pardee, unpublished results).

By comparison, however, flavins are greatly overproduced, as the present work has shown; the ratio of excreted to retained flavin ranges between $0 \cdot 8$ and 8 during exponential growth under different conditions. Several other vitamins and coenzymes are greatly overproduced during exponential growth, for example, biotin by Proteus vulgaris (Thompson, 1942), pantothenic acid (McIlwain, 1946 b; Maas, $1959 b$ ), vitamin $B_{6}$ (Nurmikko \& Laaksonen, 1961) and pyridine nucleotides (Imsande, 1961; Imsande \& Pardee, 1962) by Escherichia coli, and inositol by a strain of cultured mammalian cells (Eagle, Agranoff \& Snell, 1960; Eagle, personal communication). Considering how few attempts have been made to detect overproduction of vitamins or coenzymes by exponentially growing cultures, it would seem quite possible that all such compounds are overproduced to an extent that is large in comparison with the extent to which amino acids and nucleic-acid bases are overproduced.

In support of this, vitamins are, as a general rule, found largely in the filtrates of stationary cultures of bacteria that can synthesize them (Thompson, 1942; Knight, 1945; Van Lanen, 1948). As Thompson pointed out, this may often result from overproduction and excretion of vitamins during growth, as well as from autolysis. Vitamins are present in relatively large amounts in the filtrates of stationary cultures of fungi too, especially the flavins synthesized by ascomycetes such as Eremothecium ashbyii (Goodwin \& Pendlington, 1954), Ashbya gossypii (Maley \& Plaut, 1959; 
Smith et al. 1961), and Candida sp. (Enari, 1958; Goodwin \& McEvoy, 1959). These findings probably also apply to coenzymes because the analytical techniques used have generally not distinguished coenzymes from vitamins.

Uncoupling of growth and coenzyme synthesis. Further evidence that coenzyme synthesis is not precisely adjusted to physiological needs is given by experiments which showed that growth and coenzyme synthesis are not tightly coupled to each other. On the one hand, there is residual growth in the absence of a required vitamin, and on the other hand, there is the evidence that when growth is inhibited flavin synthesis goes on uninterrupted. Some data in the literature suggest that, like flavins but unlike amino acids an nucleic-acid bases, other vitamins and coenzymes are synthesized at a rate which cannot be adjusted quickly to a change in growth rate. Thus although there are no reports fully comparable to the present one concerning what happens to coenzyme synthesis when growth is abruptly halted, it is clear that non-growing bacteria can often synthesize vitamins in the absence of special supplements (McIlwain, 1946b; Nimmo-Smith et al. 1948; Lascelles \& Woods, 1952; Morris, 1959). Indeed, McIlwain found that when Escherichia coli or Pseudomonas aeruginosa were grown in minimal medium, then harvested in stationary phase and suspended in frosh medium lacking the nitrogen source $\left(\mathrm{NH}_{4}{ }^{+}\right)$. they would synthesize pantothenic acid at about the same rate as exponentially growing bacteria.

Disadvantages of precise adjustmint. Bacteria would probably not benefit from stricter controls over the synthesis of flavins and other coenzymes. In the first place, the waste of energy and materials entailed in overproducing flavins and other coenzymes is small. The absolute rate at which the average amino acid or nucleic-acid base is excreted is approximately as great or greater. In this sense, therefore, the controls in coenzyme pathways are as strict as those in large-scale pathways.

To avoid even this small absolute rate of excretion, control mechanisms would have to be stricter; that is, the concentration of end product required to inhibit its own synthesis (by whatever means) would have to be much lower. Perhaps lower concentrations would be too low for the end products to act as substrates for the synthesis of macromolecules. The flavin case illustrates this possibility well because, as shown in the present work, the internal concentration of free flavins in Escherichin coli is already less than $4 \times 10^{-6} \mathrm{M}$.

This work was supported by a grint, E3277, from the U.S. Public Health Service, and was done in partial fulfilment of the requirements for a Ph.D. degree awarded to one of us (A.C.W.) while he held the Abraham Rosenberg Fellowship in Biochemistry at the University of California.

\section{IREFERENCES}

Bolton, E. T., Britten, R. J., Covie, D. B. \& Roberts, R. B. (1955). Biophysics. Yearb. Carneg. Instn, 54, 75.

Brooke, M. S., Ushiba, D. \& Magasanik, B. (1954). Some factors affecting the excretion of orotic acid by mutants of Aerobicter aerogenes. J. Bact. 68, 534.

Burch, H. B. (1957). Fluorimetric assay of FAD, FMN and riboflavin. In Methods in Enzymology, III, 960. Ed. by S. P. Colowick and N. O. Kaplan. New York: Academic Press. 
DaGley, S. \& Johnson, A. R. (1956). Appearance of amino acids and peptides in culture filtrates of micro-organisms growing in mineral salt media. Biochim. biophys. Acta, 21, 270.

Davis, B. D. (1950). Studies on nutritionally deficient bacterial mutants isolated by means of penicillin. Experientia, $\mathbf{6}, \mathbf{4 1}$.

Eagle, H., Agranoff, B. W. \& Snele, E. E. (1960). 'The biosynthesis of meso-inositol by cultured mammalian cells, and the parabiotic growth of inositol-dependent and inositol-independent strains. J. biol. Chem. 235, 1891.

ENARI, T. M. (1958). Studies on the uptake of cobalt and iron and effect on the production of riboflavin by Candida guilliermondii. Ann. Acad. Sci. fennicae, Ser. A, sec. 2, $90,1$.

EnNis, H. L. \& Gorini, L. (1961). Control of arginine biosynthesis in strains of Escherichia coli not repressible by arginine. J. mol. Biol. 3, 439 .

Euler, H. von \& Adler, E. (1934). Freies Flavin und gebundenes Flavin (FlavinEnzym) in tierischen Organen und Flüssigkeiten und in Hefe. Arkiv. Kemi Min. Geol. B, 11, no. 28.

Gale, E. F. \& Folkes, J. B. (1953). The assimilation of amino-acids by bacteria, 15. Actions of antibiotics on nucleic acid and protein synthesis in Staphylococcus aureus. Biochem. J. 53, 493.

Goonwin, T. W. \& McEvoy, D. (1959). Studies on the biosynthesis of riboflavin, 5. General factors controlling flavinogenesis in the yeast Candida flareri. Biochem. J. 71, 742.

Goodwin, T. W. \& Pendlington, S. (1954). Studies on the biosynthesis of riboflavin. Nitrogen metabolism and flavinogenesis in Eremothecium ashbyii. Biochem. J. 57, 631.

Hanawalt, P. \& Setlow, R. (1960). Effect of monochromatic light on macromolecular synthesis in Escherichia coli. Biochim. biophys. Acta, 41, 283.

Imsande, J. (1961). Pathway of diphosphopyridine nucleotide biosynthesis in Escherichia coli. J. biol. Chem. 236, 1494.

Imsande, J. \& PARDEe, A. B. (1962). Regulation of pyridine nucleotide biosynthesis in Escherichia coli. J. biol. Chem. 237. (in the Press).

Kearney, E. B. \& ENGLard, S. (1951). The enzymatic phosphorylation of riboflavin. J. biol. Chem. 193, 821.

Kitay, E. \& SNell, E. E. (1948). Effect of size of inoculum on the apparent vitamin requirements of lactic acid bacteria. Proc. Soc. exp. Biol. Med. 68, 648 .

KNIGHT, B. C. J. G. (1945). Growth factors in microbiology. Some wider aspects of nutritional studies with micro-organisms. Vitam. \& Horm. 3, 105.

Lascelles, J. (1961). Synthesis of tetrapyrroles by micro-organisms. Physiol. Rev. 41, 417.

LASCElles, J. \& Woods, D. D. (1952). The synthesis of 'folic acid' by Bacterium coli and Staphylococcus aureus and its inhibition by sulphonamides. Brit. J. exp. Path. 33, 288.

LEDERBERG, J. (1950). Isolation and characterization of biochemical mutants of bacteria. Meth. med. Res. 3, 5.

Lowry, O. H., Rosebrough, N. J., Farr, A. L. \& Randall, R. J. (1951). Protein measurement with the Folin phenol reagent. J. biol. Chem. 193, 265.

MAAS, W. K. (1959a). Effect of penicillin on the uptake of amino acids in bacteria. Biochem. biophys. Res. Comm. 1, 13.

MaAs, W. K. (1959b). The biosynthesis of pantothenic acid. Congr. int. Biochem. Symp. $11,161$.

MacCormick, D. B., Gregory, M. E. \& Snell, E. E. (1961). Pyridoxal phosphokinases, I. Assay, distribution, purification and properties. J. biol. Chem. 236, 2076.

Maley, G. F. \& Plaut, G. W. E. (1959). The isolation, synthesis and metabolic properties of 6,7-dimethyl-8-ribityllumazine. J. biol. Chem. 234, 641 .

McIlwain, H. (1946a). The magnitude of microbial reactions involving vitamin-like compounds. Nature, Lond., 158, 898.

McIllwain, H. (1946 b). The metabolism and functioning of vitamin-like compounds, 2 . A comparison of pantothenate metabolism by proliferating and non-proliferating bacteria. Biochem. J. 40, 269. 
Mrtcheld, P. \& Moxцe, J. (1956). Osmotic function and structure in bacteria. In Bacterial Anatomy. Symp. Soc. gen. Microbiol. 6, 150.

Morris, J. G. (1959). 'The synthesis of vitamin $\mathrm{B}_{6}$ by some mutant strains of Escherichia coli. J. gen. Microbiol. 20, 597.

Moyed, H. S. (1960). False feedback inhibition: inhibition of tryptophan biosynthesis by 5-methyltryptophan. J. biol. Chem. 235, 1098.

Newton, B. A. (1958). Surface-active bactericides. In The Strategy of Chemotherapy. Symp. Soc. gen. Microbiol. 8, 62.

Nimmo-Smith, R. H., Lascelles, J. \& Woods, D. D. (1948). The synthesis of 'folic acid' by Streptobacterium plantarum and its inhibition by sulphonamides. Brit. J. exp. Path. 29, 264.

Nurmikкo, V. \& LaAksonen, S. (1961). Biosynthesis and excretion of vitamin $B_{6}$ by Escherichia coli during the exponential phase of growth. Acta chem. fenn. B, 34, 7 .

Pardee, A. B. (1955). Effect of energy supply on enzyme induction by pyrimidine requiring mutants of Escherichia coli. J. Bact. 69, 233.

Pardee, A. B. (1957). An inducible: mechanism for the accumulation of melibiose in Escherichia coli. J. Bact. 73, 376.

Pardee, A. B. (1959). The control of (nzyme activity. In The Enzymes (second edition) I, 681. Ed. by P. D. Boyer, H. Lardy \& K. Myrbäck. New York: Academic Press.

Pardee, A. B. \& Prestroge, L. S. (19:59). On the nature of the repressor of $\beta$-galactosidase synthesis in Escherichia coli. Biochim. biophys. Acta, 36, 545.

Parder, A. B., Shore, V. G. \& Prestidge, L. S. (1956). Incorporation of azatryptophan into proteins of bacteria and bacteriophage. Biochim. biophys. Acta, 21, 406.

PeEL, J. L. (1958). The separation of flavins by paper electrophoresis and its application to the examination of the flavin contents of micro-organisms. Biochem. J. 69, 403 .

Plaut, G. W. E. (1954). Biosynthesis of riboflavin, I. Incorporation of $\mathrm{C}^{14}$-labelled compounds into rings $\mathrm{B}$ and C. J. biol. Chem. 208, 513.

Plaut, G. W. E. (1960). Studies on the stoichiometry of the enzymic conversion of 6,7dimethyl-8-ribityllumazine to riboflavin. J. biol. Chem. 235, PC41.

Prestidge, L. S. \& Pardee, A. B. (1957). Induction of bacterial lysis by penicillin. J. Bact. 74, 48.

Roberts, R. B., Abelson, P. H., Cowme, D. B., Bolton, E. T. \& Britten, R. J. (1955). Studies of biosynthesis in Escherichia coli. Publ. Carneg. Instn (Wash.), 607, 1.

Roe, J. H., Epstein, J. H. \& Golds'ein, N. P. (1949). A photometric method for the determination of inulin in plasma and urine. J. biol. Chem. 178, 839.

Rushizky, G., Riley, M., Prestingle, L. S. \& Pardee, A. B. (1960). Inactivation of enzyme formation by ultraviolet light, I. Action spectra and the size of the sensitive unit. Biochim. biophys. Acta, 45, 70.

Schrecker, A. W. \& Kornberg, A. (1950). Reversible enzymatic synthesis of flavinadenine dinucleotide. J. biol. Chem. 182, 795.

Sнiota, T. (1959). Enzymic synthesis of folic acid-like compounds by cell-free extracts of Lactobacillus arabinosus. Arch. Biochem. Biophys. 80, 155.

Singer, T. P., Kearney, E. B. \& Masisey, V. (1956). Observations on the flavin moiety of succinic dehydrogenase. Arch. Biochem. Biophys. 60, 255.

Smith, C. G., Smith, G. A. \& Papadoupoulou, Z. (1961). Effects of surface active agents on the biosynthesis of riboflavin by Ashbya gossypii. Biochim. biophys. Acta, 47, 344.

Snoswell, A. M. (1957). Flavokinase of Lactobacillus arabinosus 17.5. Aust. J. exp. Biol. med. Sci. 35, 427.

SNELL, E. E. (1950). Microbiological methods in vitamin research. In Vitamin Methods, I, 327. Ed. P. György. New York: Academic Press.

Thompson, R. C. (1942). Synthesis of 3 vitamins by bacteria in pure culture. Univ. Tex. Publ. No. 4237, 87.

Troll, W. \& Cannan, R. K. (1953). A modified photometric ninhydrin method for the analysis of amino and imino acids. I. biol. Chem. 200, 803.

VAN LANEN, J. M. (1948). Vitamins in microorganisms-distribution and quantitative syntheses. Vitam. \& Horm. 6, 163. 
Warringa, M. G. P. J. \& Giuditta, A. (1958). Studies on succinic dehydrogenase, IX. Characterization of the enzyme from Micrococcus lactilyticus. J. biol. Chem. $230,111$.

Webs, M. (1954). The effects of folic acid analogues on the growth and cell division of micro-organisms. In The Chemistry and Biology of Pteridines, Ciba Foundation Symposium, p. 253. Boston: Little, Brown and Co.

Weiss, B. \& Srinivasan, P. R. (1959). The biosynthesis of $p$-aminobenzoic acid. Proc. nat. Acad. Sci., Wash. 45, 1491.

Wilson, A. C. \& Pardee, A. B. (1962). Comparative aspects of metabolic control. In Comparative Biochemistry, V. Ed. by M. Florkin \& H. S. Mason. New York: Academic Press. (In the Press.)

Wisseman, C. L., Smader, J. E., Hahn, F. E. \& Hopps, H. E. (1954). Mode of action of chloramphenicol, I. Action of chloramphenicol on assimilation of ammonia and on synthesis of proteins and nucleic acids. J. Bact. 67, 662 . 